\title{
Thermal Characteristics of Multilayer Insulation Materials for Flexible Thin-Film Solar Cell Array of Stratospheric Airship
}

\author{
Kangwen Sun,, Qinzhen Yang, ${ }^{1}$ Yang Yang, ${ }^{2}$ Shun Wang, ${ }^{2}$ Jianming Xu, \\ Qiang Liu, ${ }^{1}$ Yong Xie, ${ }^{1}$ and Peng Lou ${ }^{1}$ \\ ${ }^{1}$ School of Aeronautic Science and Technology, Beihang University, Beijing 100191, China \\ ${ }^{2}$ Shanghai Institute of Space Power Sources (SISP), Shanghai 200245, China \\ Correspondence should be addressed to Qinzhen Yang; yqz1210@126.com
}

Received 2 August 2014; Revised 15 November 2014; Accepted 24 November 2014; Published 9 December 2014

Academic Editor: Chi-Wai Chow

Copyright (C) 2014 Kangwen Sun et al. This is an open access article distributed under the Creative Commons Attribution License, which permits unrestricted use, distribution, and reproduction in any medium, provided the original work is properly cited.

Flexible thin-film solar cell is an efficient energy system on the surface of stratospheric airship for utilizing the solar energy. In order to ensure the normal operation of airship platform, the thermal control problem between the flexible thin-film solar cell and the airship envelope should be properly resolved. In this paper, a multilayer insulation material (MLI) is developed first, and low temperature environment test is carried out to verify the insulation effect of MLI. Then, a thermal heat transfer model of flexible thin-film solar cell and MLI is proposed, and the equivalent thermal conductivity coefficients of flexible thin-film solar cell and Nomex honeycomb are calculated based on the environment test and the temperature profile of flexible thin-film solar cell versus each layer of MLI. Finally, FLUENT is used for modeling and simulation analysis on the flexible thin-film solar cell and MLI, and the simulation results agree well with the experimental data, which validate the correctness of the proposed heat transfer model of MLI. In some way, our study can provide helpful support for further engineering applications of flexible thin-film solar cell.

\section{Introduction}

As a high-altitude platform, stratospheric airships are widely used in many important fields, especially in communication, broadcasting, remote sensing, scientific research, and so forth. Currently, United States, Japan, and South Korea are the major countries to develop stratospheric airships [1-10].

Solar energy is an ideal choice to provide power for highaltitude and long-endurance airships. This type of power system is actually a photovoltaic (PV) array coupled to an energy storage system [2]. The efficiency, mass, surface shape, and position of the PV array significantly influence the airship performance, whereas the PV array performance depends on its operation conditions such as latitude, time, temperature, and geometry. Therefore, the PV array and its operation conditions are critical to the airship design and capabilities. Besides, the PV array also has significant effects on the temperature profile of the airship hull, which can enhance the "superheat" or "supercool" of airship [9].
In the past decade, many investigations have been carried out on the energy system of the stratospheric airship. Harada et al. [5] conducted experiments on the thermal characteristics of a 35-meter-long low-altitude airship equipped with PV array, which was developed as a flying test bed for the development of stratospheric airship. Naito et al. [6] proposed the design and analysis of solar energy power system for stratospheric airship operations. Shi et al. [7] studied the solar energy collected by stratosphere airship's surface. Zheng et al. [8] studied the solar power and power output characteristics of the solar cell array of a stratospheric airship. Li et al. [9] investigated the thermal characteristics of photovoltaic array of a stratospheric airship. In addition, Eskind et al. [10] mentioned a thermal control measure by using $7 \mathrm{~mm}$ thick insulation panels between the solar cell array and the envelope. Overall, current investigations mostly focus on the power system but seldom pay attention to the insulation of stratospheric airship solar array. 
According to the characteristics of stratospheric airship envelope and flexible thin-film solar cell, this paper develops a multilayer insulation material (MLI) and then proposes a heat transfer model for the MLI. Further, in order to verify the insulation effect of MLI and get the temperature profile of flexible thin-film solar cell and each MLI layer, an experimental test is carried out to calculate the equivalent thermal conductivity coefficient of flexible thin-film solar cell and Nomex honeycomb. Finally, FLUENT is used for modeling and simulation analysis on the flexible thin-film solar cell and MLI.

\section{Physical Model}

MLI is a commonly used material in multilayer insulation for space vehicles. It can be composed of multilayer reflector screens, or laminated together with spacer. Since the flexible thin-film solar cell and the hull of stratospheric airship are both of flexible structures, considering the environment of stratosphere, MLI can be applied to insulation of the flexible thin-film solar cell. Yinbing et al. [11] developed an $\mathrm{Al} / \mathrm{PI} / \mathrm{SiO}_{2}$ multilayer insulation film with $\mathrm{Al}$ film as the heat reflective screen, silicone nano-composite coating as the low thermal conductivity layer, and polyimide (PI) as the flexible substrate. Weidong et al. [12] obtained the patent of a thin flexible insulation composite fabric. Ahluwalia et al. [13] developed a flexible multilayer composite insulation material which was made of metal foil (film) and flexible foam layer. These MLIs have good flexibility, light weight, and good heat insulation performance, but their mechanical strength is very weak. For example, the tensile strength of PI is $200 \mathrm{MP}$ at $20^{\circ} \mathrm{C}$ and temperature rise can further decrease its tensile strength.

Based on existing flexible insulation structures and enhancement structures, we develop an MLI by virtue of PET, fiberglass mesh, epoxy resin film, and Nomex honeycomb. The PET film can be used as the substrate to which the fiberglass and Nomex honeycomb are attached. The fiberglass has high mechanical strength and can be used as the enhancement structure. The epoxy resin film can be used as adhesive to combine each layer together. The Nomex honeycomb is a hollow flexible insulation material and has a good capability of thermal insulation. The structure of MLI is shown as Figure 1.

\section{Analysis of Heat Transfer Process}

3.1. Heat Transfer Model. The structure is composed of the thin film solar cell, PET, fiberglass mesh, epoxy resin film, Nomex honeycomb, and airship hull. Thermal property of each layer is different, and solar radiation absorbed on different parts of the thin film solar cell is nonuniform. Thus, the thin film solar cell can be treated as a heat conductor with nonuniform inner heat source. In view of this, a separate heatbalance equation should be written for each layer to obtain a better estimation of the temperature. The heat transfer mechanism of the structure is shown as Figure 2, which can

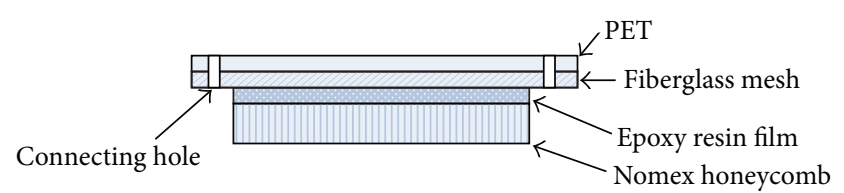

FIgURE 1: Structure of MLI.

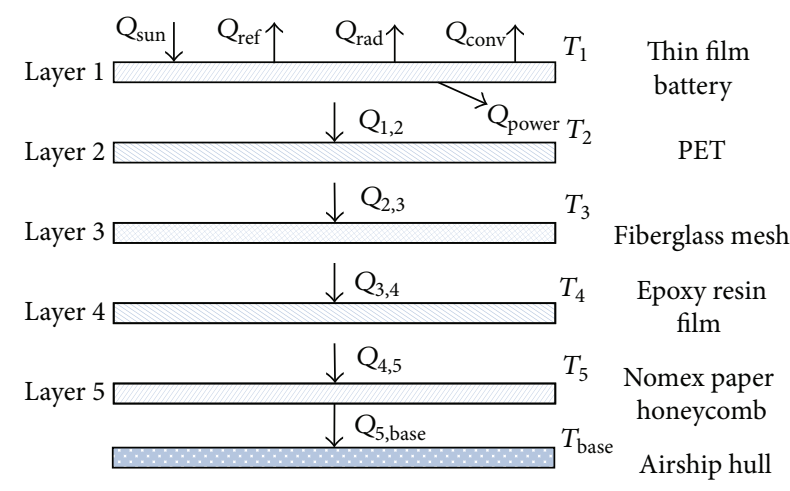

FIGURE 2: MLI heat transfer model.

be expressed by the following five differential time-dependent equations:

$$
\begin{gathered}
m_{1} c_{1} \frac{d T_{1}}{d \tau}=Q_{\text {sun }}-Q_{\text {ref }}-Q_{\text {rad }}-Q_{\text {conv }}-Q_{\text {power }}-Q_{1,2} \\
m_{2} c_{2} \frac{d T_{2}}{d \tau}=Q_{1,2}-Q_{2,3} \\
m_{3} c_{3} \frac{d T_{3}}{d \tau}=Q_{2,3}-Q_{3,4} \\
m_{4} c_{4} \frac{d T_{4}}{d \tau}=Q_{3,4}-Q_{4,5} \\
m_{5} c_{5} \frac{d T_{5}}{d \tau}=Q_{4,5}-Q_{5, \text { base }}
\end{gathered}
$$

where

$$
\begin{gathered}
Q_{i, i+1}=\frac{A\left(T_{i}-T_{i+1}\right)}{\left(\delta_{i} / \lambda_{i}\right)+\left(\delta_{i+1} / \lambda_{i+1}\right)} \\
Q_{5, \text { base }}=\frac{A\left(T_{5}-T_{\text {base }}\right)}{\left(\delta_{5} / \lambda_{5}\right)+\left(\delta_{\text {base }} / \lambda_{\text {base }}\right)} \\
Q_{\text {sun }}=A * I_{0} \\
Q_{\text {ref }}=A * r * I_{0} \\
Q_{\text {power }}=A * a * I_{0},
\end{gathered}
$$

where $A$ is the area of flexible thin-film solar cell, $\mathrm{m}^{2} ; I_{0}=$ $1367 \mathrm{w} / \mathrm{m}^{2}$ is the solar constant; $r$ is the reflectivity of flexible thin-film solar cell; $a$ is the conversion efficiency of solar cell; $m_{i}$ is the mass of Layer $I, \mathrm{~kg}$; and $c_{i}$ is the specific heat capacity of the material of Layer $i, \mathrm{~J} /(\mathrm{kg} \cdot \mathrm{K})$. 
The radiation heat loss on the surface of thin film solar cell is given by

$$
Q_{\mathrm{rad}}=A \varepsilon \sigma\left(T_{1}^{4}-T_{\infty}^{4}\right),
$$

where $\varepsilon$ is the emissivity of flexible thin-film solar cell; $\sigma$ is the constant of Stefan-Boltzmann, $\sigma=5.67 \times 10^{-8} \mathrm{~W} /\left(\mathrm{m}^{2} \cdot \mathrm{K}^{4}\right) ; T_{1}$ is the temperature of the upside of flexible thin-film solar cell, $\mathrm{K}$; and $T_{\infty}$ is the sky equivalent temperature, $\mathrm{K}$.

The conductive heat loss is given by

$$
Q_{\text {conv }}=A h\left(T_{1}-T_{\infty}\right),
$$

where $h$ is the convection heat transfer coefficient. $h$ can be given by

$$
h=\frac{N_{u} \lambda_{\text {air }}}{L},
$$

where $L$ is the characteristic length, $\mathrm{m} ; \lambda_{\text {air }}$ is the thermal conductivity of air,

$$
\lambda_{\text {air }}=0.0241\left(\frac{T_{m}}{273.15}\right)^{0.9} ;
$$

$T_{m}=0.5 \times\left(T_{1}+T_{\infty}\right)$ is the characteristic temperature; and $N_{u}$ is the Nusselt number:

$$
N_{u}= \begin{cases}0.54\left(G_{r} \cdot P_{r}\right)^{1 / 4} & 2 \times 10^{4} \leq G_{r} \cdot P_{r} \leq 8 \times 10^{6} \\ 0.15\left(G_{r} \cdot P_{r}\right)^{1 / 3} & 8 \times 10^{6} \leq G_{r} \cdot P_{r} \leq 1 \times 10^{11},\end{cases}
$$

where $P_{r}$ is the Prandtl number, $P_{r}=0.804-3.25 \times 10^{-4} \times T_{m}$; and $G_{r}$ is the Grashof number, $G_{r}=\left(g \cdot \alpha \cdot\left(T_{1}-T_{\infty}\right) \cdot L^{3}\right) / \vartheta^{2}$, in which $g$ is the acceleration of gravity; $\alpha$ is the coefficient of cubic expansion, $1 / \mathrm{K}$; and $\vartheta$ is the kinematic viscosity of air, $\mathrm{m}^{2} / \mathrm{s}$.

To calculate the thermal conductivity of flexible thin-film solar cell and Nomex honeycomb accurately, an experiment is designed to obtain the equivalent thermal conductivity coefficient.

\subsection{Thermal Conductivity of Flexible Thin-Film Solar Cell.} The surface of flexible thin-film solar cell is exposed to ambient air. The exposed area is $A$ and the temperature of ambient air is $T_{\infty}$. When the solar radiation intensity is $I_{0}$, the upside and downside temperatures of flexible thin-film solar cell are $T_{\text {up }}$ and $T_{\text {down }}$ when the solar radiation intensity is, respectively.

The structure of flexible thin-film solar cell is shown in Figure 3.

The flexible thin-film solar cell is composed of PET, EVA, and single-junction amorphous silicon cells, which can be treated as a multilayer model. Parameters of the flexible thinfilm solar cell are listed in Table 1.

To simplify the energy model of flexible thin-film solar cell, it is assumed that a portion of solar flux is absorbed by the solar cell while the other part is reflected back to the atmosphere. The surface has convective heat transfer with the atmosphere. The flexible thin-film solar cell has conductive

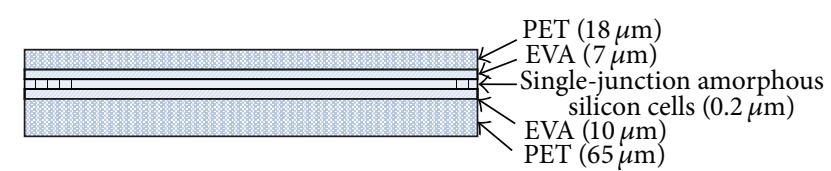

Figure 3: Structure of flexible thin-film solar cell.

heat transfer with the MLI. The mechanism of heat transfer of the flexible thin-film solar cell is shown in Figure 4.

According to the mechanism of heat transfer of the flexible thin-film solar cell, steady-state energy equation of flexible thin-film solar cell can be established. Thus, when the $T_{\text {up }}, T_{\text {down }}, T_{\infty}$, and $I_{0}$ are obtained, we can calculate the thermal conductivity of flexible thin-film solar cell:

$$
\begin{gathered}
\mathrm{AI}_{0}=Q_{\mathrm{ref}}+Q_{\mathrm{rad}}+Q_{\text {conv }}+Q_{\text {power }}+Q_{\text {cond }}, \\
Q_{\text {cond }}=A \lambda \frac{T_{\text {up }}-T_{\text {down }}}{\delta},
\end{gathered}
$$

where $\lambda$ is the equivalent thermal conductivity of flexible thin-film solar cell; and $\delta$ is the thickness of flexible thin-film solar cell.

Since each layer of the flexible thin-film solar cell is tightly laminated together, the thermal contact resistance can be ignored. Thus, the thermal conductivity can be given by

$$
\frac{\delta}{\lambda}=\frac{\delta_{1}}{\lambda_{1}}+\frac{\delta_{2}}{\lambda_{2}}+\frac{\delta_{3}}{\lambda_{3}}+\frac{\delta_{4}}{\lambda_{4}}+\frac{\delta_{5}}{\lambda_{5}}
$$

where $\delta_{1}, \delta_{2}, \delta_{3}, \delta_{4}$, and $\delta_{5}$ are the thickness and $\lambda_{1}, \lambda_{2}, \lambda_{3}$, $\lambda_{4}$, and $\lambda_{5}$ are the thermal conductivity of each layer of the flexible thin-film solar cell. Then, the thickness of the flexible thin-film solar cell can be given by

$$
\delta=\delta_{1}+\delta_{2}+\delta_{3}+\delta_{4}+\delta_{5} .
$$

The conductive heat can be calculated from the steadystate energy equation, and then we can get the thermal conductivity of the flexible thin-film solar cell according to (5)-(8).

\subsection{Equivalent Thermal Conductivity of Nomex Honeycomb.} Nomex honeycomb is used at the bottom of the MLI. The Nomex honeycomb layer has conductive heat transfer with the adjacent epoxy resin film layer. To establish the calculation model of equivalent thermal conductivity of Nomex honeycomb, it is necessary to study the cell unit of honeycomb, as shown in Figures 5 and 6.

The side length of Nomex honeycomb is $l=1.83 \times 10^{-3} \mathrm{~m}$, the height is $H=5.5 \times 10^{-3} \mathrm{~m}$, and the wall thickness of single layer is $t=0.2 \times 10^{-3} \mathrm{~m}$. According to the results of Liang et al. [14], convection heat transfer of air inside honeycomb can be ignored. Hence, heat transfer model of the honeycomb mainly consists of solid heat conduction of the sandwich layer of cell wall, air heat conduction inside the honeycomb, and radiation heat transfer between honeycomb 
TABle 1: Parameters of each layer of the thin-film solar cell.

\begin{tabular}{|c|c|c|c|c|c|}
\hline Material & Thickness $\left(10^{-6} \mathrm{~m}\right)$ & $\begin{array}{l}\text { Thermal conductivity } \\
(\mathrm{W} /(\mathrm{m} \cdot \mathrm{K}))\end{array}$ & Emissivity & Transmittance & $\begin{array}{c}\text { Photoelectric conversion } \\
\text { efficiency }\end{array}$ \\
\hline PET & 18 & 0.22 & 0.92 & $90 \%$ & - \\
\hline EVA & 7 & 0.25 & - & $91 \%$ & - \\
\hline $\mathrm{A}-\mathrm{Si}$ & 0.2 & - & - & - & $2.22 \%$ \\
\hline EVA & 10 & 0.25 & - & $91 \%$ & - \\
\hline PET & 65 & 0.22 & 0.92 & $90 \%$ & - \\
\hline
\end{tabular}

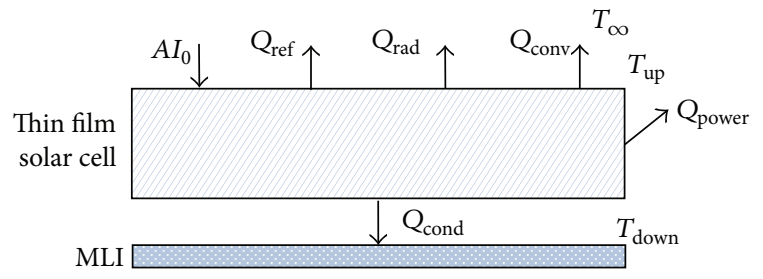

FIGURE 4: Mechanism of heat transfer of the flexible thin-film solar cell. cell wall and the upper and lower panels. The equivalent thermal conductivity can be given by

$$
\lambda_{n}=\lambda_{f} \frac{\Delta A}{A}+\lambda_{a}\left(1-\frac{\Delta A}{A}\right)+\lambda_{r}
$$

where $\lambda_{f}$ is the thermal conductivity of the thin foil parent material of honeycomb; $\lambda_{a}$ is the thermal conductivity of air inside the honeycomb; $\lambda_{r}$ is the radiation thermal conductivity of honeycomb cell wall and the upper and lower panels; $\Delta A$ is the cross-sectional area of honeycomb core material, $\Delta A=16 \mathrm{lt}$; and $A$ is the cross-sectional area of cell unit, $A=6 \sqrt{3} l^{2}$.

Thermal conductivity of air inside the honeycomb is given by

$$
\lambda_{a}=0.0241\left(\frac{T_{a}}{273.15}\right)^{0.9},
$$

where $T_{a}=\left(T_{1}+T_{2}\right) / 2$ is the characteristic temperature, in which $T_{1}$ and $T_{2}$ are the temperatures of the upside and down side of honeycomb.

Radiation thermal conductivity of honeycomb is given by Swarm and Pittman [15]:

$$
\begin{aligned}
\lambda_{r}= & 0.664(\eta+0.3)^{-0.69} H \varepsilon^{1.63(\eta+1)^{-0.89}} \\
& \times \sigma\left(T_{1}+T_{2}\right)\left(T_{1}^{2}+T_{2}^{2}\right)
\end{aligned}
$$

where $\eta=H / l$ is the ratio of the height and side length of the honeycomb; $\varepsilon$ is the emissivity inside the honeycomb; $\sigma=5.67 \times 10^{-8} \mathrm{~W} / \mathrm{m}^{2} \cdot \mathrm{K}^{4}$ is Stefan-Boltzmann constant; and $T_{1}$ and $T_{2}$ are unknown. In order to determine $T_{1}$ and $T_{2}$, iterative calculations are required. In this paper, according to the experimental test data, $T_{1}=T_{5}$ and $T_{2}=T_{\text {base }}$.

\section{Experimental Test}

In this section, an experimental test is carried out to verify the insulation effect of the MLI, as well as to calculate the thermal conductivity of flexible thin-film solar cell and Nomex honeycomb accurately. Besides, the heat transfer model is also validated by the experimental test.

The dimensions of environmental cabin are $D \times L=$ $1.8 \mathrm{~m} \times 3.5 \mathrm{~m}$. Two pieces of flexible thin-film solar cell are put in the environmental cabin, and their dimensions are $0.24 \mathrm{~m} \times 0.22 \mathrm{~m}$. The temperature of the environmental cabin

Figure 6: Cell unit of honeycomb. 
is $-56^{\circ} \mathrm{C}$, and the pressure is $5 \mathrm{kPa}$. Radiant intensity of solar simulator is $1260 \mathrm{~W} / \mathrm{m}^{2}$. Test specimen 1 is just flexible thinfilm solar cell, which is used to test the temperatures of the upside and downside of flexible thin-film solar cell, as shown in Figure 7. Test specimen 2 is composed of flexible thin-film solar cell and MLI, which is used to test the temperatures of the upside and downside of flexible thin-film solar cell as well as the temperature of the downside of MLI, as shown in Figure 8.

Taking test specimen 2 as an example, temperature sensors 1 and 2 are at the upside of the thin film solar cell, temperature sensors 3 and 4 are at the downside of the thin film solar cell, and temperature sensors 5 and 6 are at the downside of the MLI. Here, sensor 1 corresponds to sensors 3 and 5 , and sensor 2 corresponds to sensors 4 and 6 . Figure 9 illustrates the test circuit diagram.

Temperature data are recorded by temperature inspection instrument until temperature change $<3^{\circ} \mathrm{C} / 10 \mathrm{~min}$. The test data of test specimen 1 and test specimen 2 are shown in Figures 10 and 11, respectively.

$T_{\text {lup1 }}$ and $T_{1 \text { up2 }}$ are the temperatures of the upside of test piece 1. $T_{1 \text { down1 }}$ and $T_{1 \text { down2 }}$ are the temperatures of the downside of test piece 1. $T_{1 \text { up }}\left(T_{\text {lup }}=\left(T_{1 \text { up } 1}+T_{1 \text { up } 2}\right) / 2\right)$ and $T_{1 \text { down }}\left(T_{1 \text { down }}=\left(T_{1 \text { down1 }}+T_{1 \text { down2 }}\right) / 2\right)$ are the average temperatures of the upside and downside of thin film solar cell, respectively.

$T_{2 \text { up1 }}$ and $T_{2 \text { up2 }}$ are the temperatures of the upside of test piece $2 . T_{2 \text { middle1 }}$ and $T_{2 \text { middle2 }}$ are the temperatures of the downside of thin film solar cell of test piece 2. $T_{2 \text { down } 1}$ and $T_{2 \text { down2 }}$ are the temperatures of the downside of the MLI of test piece 2. $T_{\text {2up }}\left(T_{\text {2up }}=\left(T_{\text {2up1 }}+T_{\text {2up } 2}\right) / 2\right)$ and $T_{2 \text { middle }}\left(T_{2 \text { middle }}=\left(T_{2 \text { middle1 }}+T_{2 \text { middle } 2}\right) / 2\right)$ are the average temperatures of the upside and downside of thin film solar cell, respectively. $T_{2 \text { down }}\left(T_{2 \text { down }}=\left(T_{2 \text { down1 }}+T_{2 \text { down2 }}\right) / 2\right)$ is the average temperature of the downside of the MLI.

\section{Computational Simulation and Analysis}

According to the test data of test specimen 1, the steady temperatures of the upside and downside of the flexible thinfilm solar cell are $65.5^{\circ} \mathrm{C}$ and $63^{\circ} \mathrm{C}$, respectively. According to (5)-(8), the thermal conductivity of flexible thin-film solar cell is $\lambda=0.2246 \mathrm{~W} /(\mathrm{m} \cdot \mathrm{k})$. Figure 11 shows that the steady temperature of the downside of the Nomex honeycomb is $25.5^{\circ} \mathrm{C}$. According to the test data of test specimen 2 and (1)-(7) and (12)-(14), through iterative calculation, the final thermal conductivity of Nomex honeycomb is $\lambda=$ $0.021 \mathrm{~W} /(\mathrm{m} \cdot \mathrm{k})$, as shown in Figure 12.

Figure 13 shows the simulation temperature profile of the multilayer insulation. $T_{1}=61^{\circ} \mathrm{C}$ is the average steady temperature of flexible thin-film solar cell, which is measured from test specimen 2. $T_{2}, T_{3}, T_{4}$, and $T_{5}$ are the simulation temperatures of PET, fiberglass mesh, epoxy resin film, and Nomex honeycomb, respectively, and their final steady temperatures are $59.5^{\circ} \mathrm{C}, 58^{\circ} \mathrm{C}, 39.3^{\circ} \mathrm{C}$, and $24.4^{\circ} \mathrm{C}$. It can be seen that the temperatures of flexible thin-film solar cell, PET, and fiberglass mesh are more or less the same, whereas the temperatures of the epoxy resin film and Nomex honeycomb

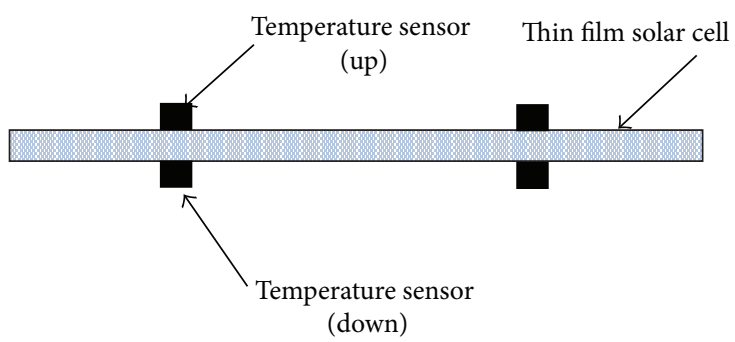

Figure 7: Test specimen 1.

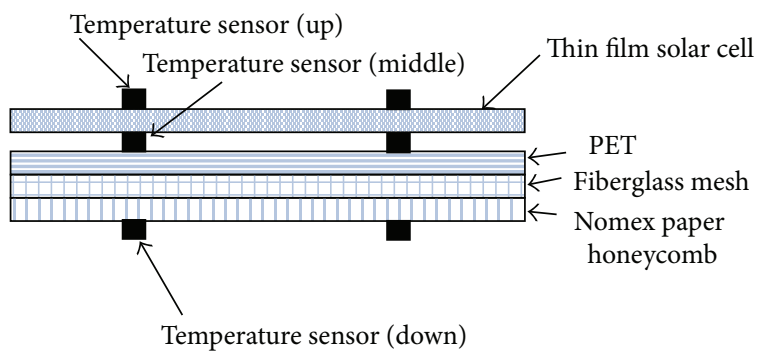

FIgURE 8: Test specimen 2.

decrease dramatically due to their large thermal resistance caused by the hollow structure.

Figure 14 shows the comparison of simulation results with relevant test data of $T_{\text {base }}$. The absolute error of simulation results relative to relevant test data is less than $2^{\circ} \mathrm{C}$; namely, the relative error of the temperature of $T_{\text {base }}$ is within $5 \%$. Therefore, the simulation results are accurate and reliable.

Finally, to investigate the applicability of the numerical model of MLI, FLUENT is used for modeling and simulation analysis on the flexible thin-film solar cell and MLI. To simplify the model, a $24 \mathrm{~cm} \times 22 \mathrm{~cm} \times 0.6 \mathrm{~cm}$ three-dimensional model of flexible thin-film solar cell and MLI is put in a fixed computational domain.

Solar load model is used to calculate the effect of solar irradiation on temperature distribution of the thin film battery. This model includes direct solar irradiation, diffuse solar irradiation, and ground-reflected solar radiation. Two options, Fair Weather Conditions method and Theoretical Maximum method, are, respectively, put forward for computing the solar load in the software, and Theoretical Maximum method is proved to be more appropriate for stratosphere and outer surface where little atmospheric extinction happens. The equation for this method is

$$
E_{d}=c I,
$$

where $c$ is the correction factor used to modify the reduction of solar irradiation due to aerosphere.

The material of the wall around the computational domain is supposed to be copper (absorptance and emittance are all 0.98 ). Temperature of the wall is $-56^{\circ} \mathrm{C}$. Solar radiation enters the computational domain from the top, and the bottom is set as outflow. Air in the computational domain is set as incompressible-ideal-gas. DO radiation model and DO irradiation model are chosen. Direct solar radiation and 
Temperature-pressure-solar radiation environmental cabin
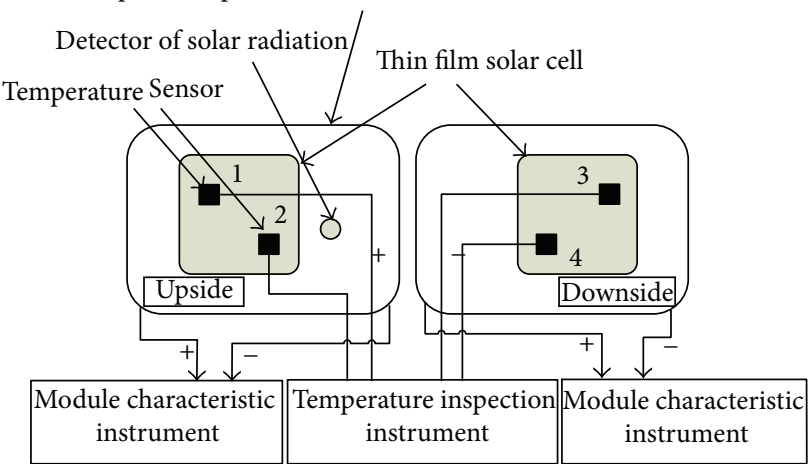

Figure 9: Test circuit diagram.

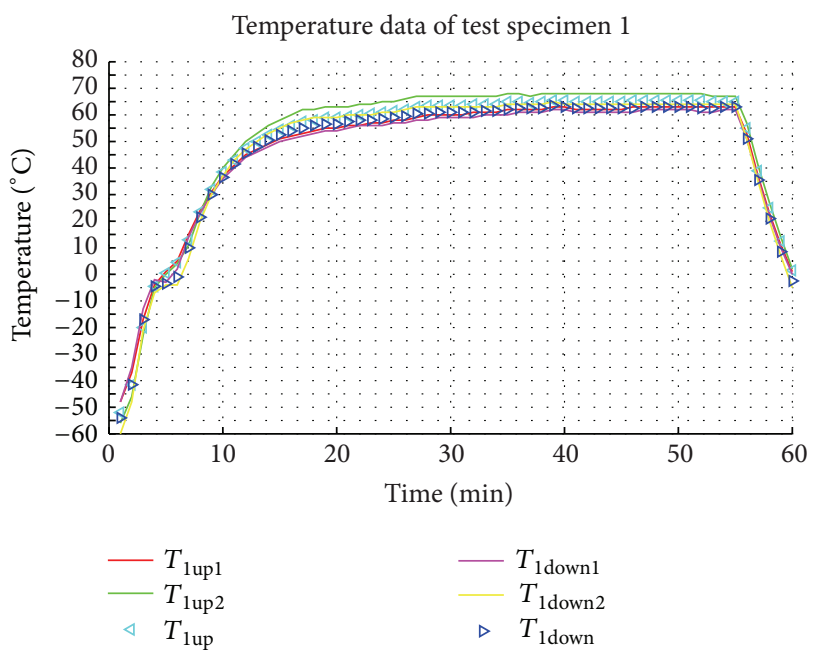

FIgURE 10: Test temperature data of test specimen 1.

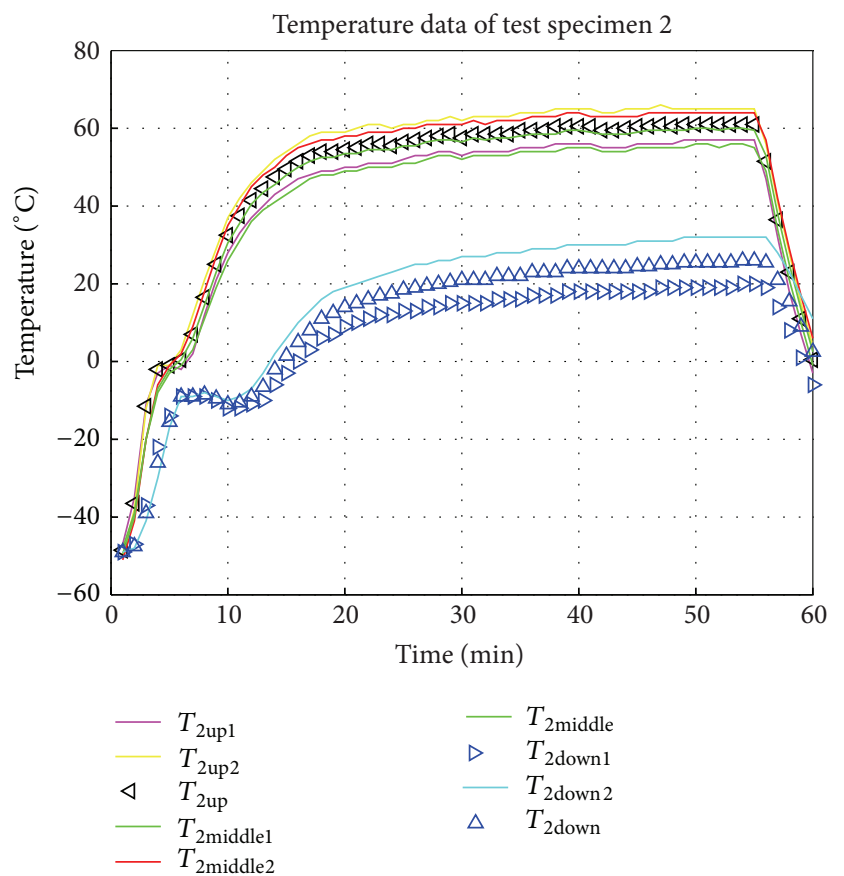

FIGURE 11: Test temperature data of test specimen 2.

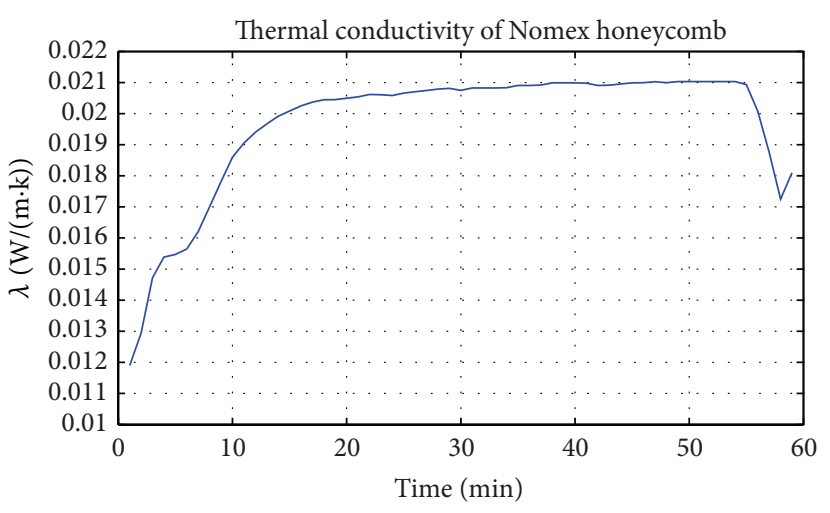

FIgURE 12: Thermal conductivity of Nomex honeycomb.

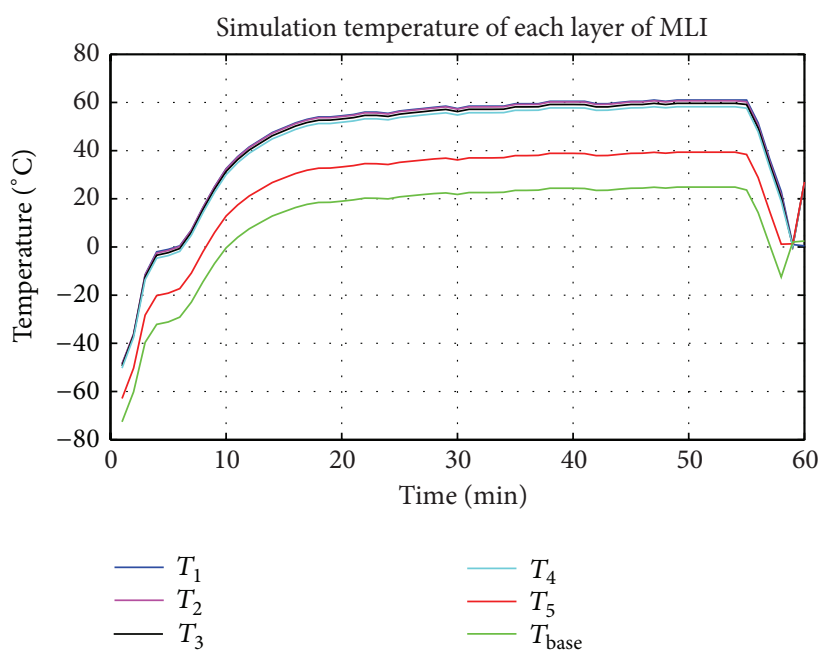

FIGURE 13: Simulation temperature of each layer.

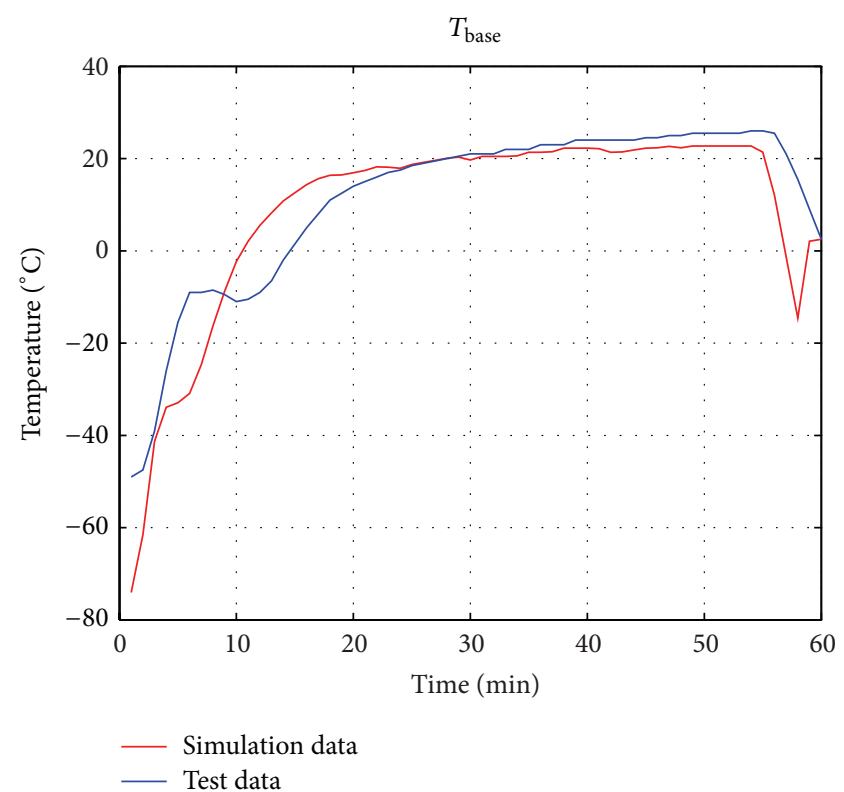

FIgURE 14: Simulation result and relevant test data of $T_{\text {base }}$. 


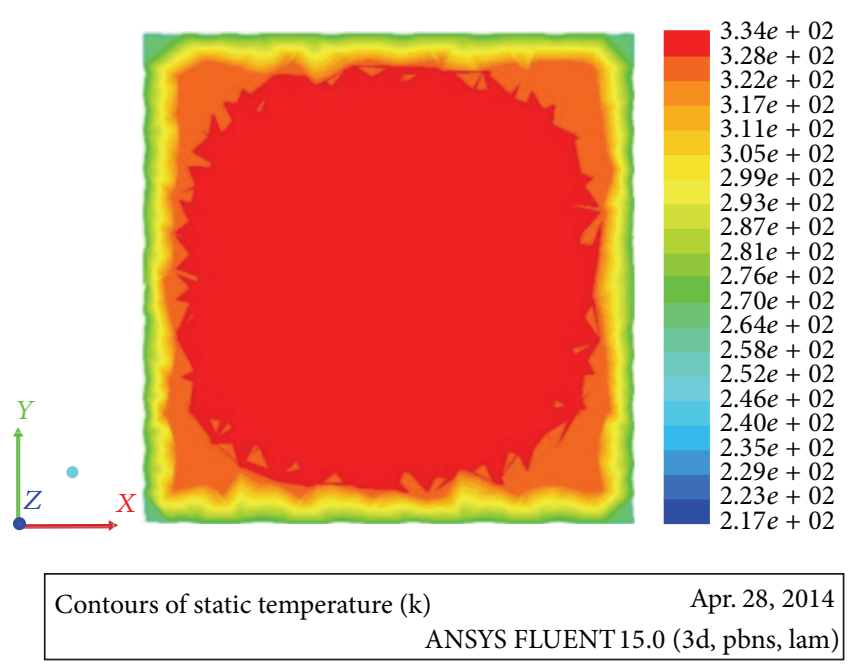

(a)

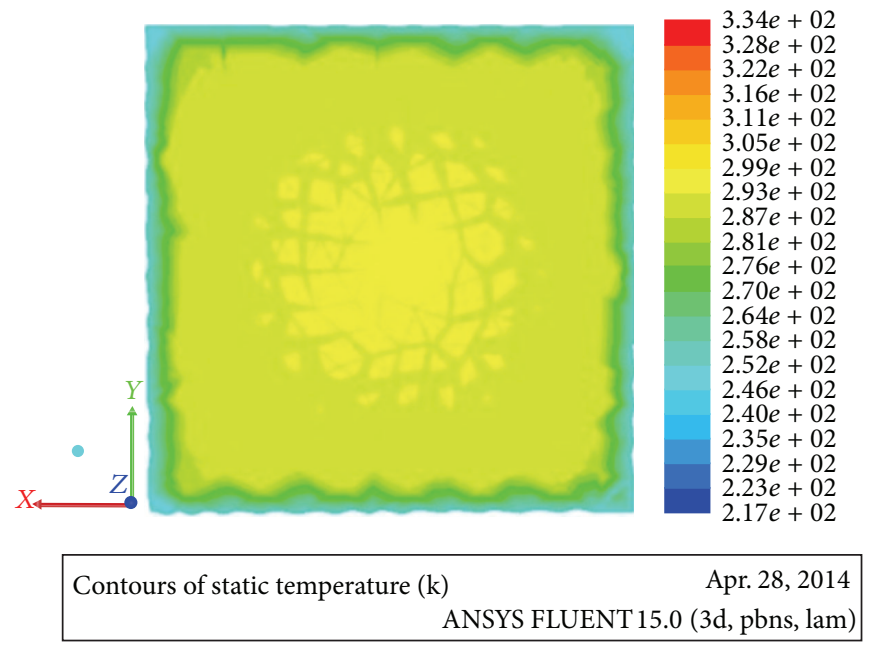

(b)

Figure 15: Temperature distribution on upside of the thin film cell and downside of the MLI.

diffuse solar radiation are calculated by solar calculator. After a 50 min calculation, the accurate temperatures of the upside and downside of the flexible thin-film solar cell and MLI can be obtained, as shown in Figure 15.

Figure 15 shows that the highest temperature of the surface of flexible thin-film solar cell is $336 \mathrm{~K}\left(63^{\circ} \mathrm{C}\right)$, and the highest temperature of the downside of MLI is $295 \mathrm{~K}\left(22^{\circ} \mathrm{C}\right)$, with the temperature decreasing from center to around. For the upside of flexible thin-film solar cell, the absolute error of simulation result relative to test data is about $2.4^{\circ} \mathrm{C}$, and the relative error is within $10 \%$. For the downside of MLI, the absolute error of simulation result relative to test data is about $2^{\circ} \mathrm{C}$, and the relative error is within $3 \%$. Therefore, the simulation results are accurate and reliable.

\section{Conclusions}

This paper developed a multilayer insulation material (MLI) according to the characteristics of stratospheric airship hull and flexible thin-film solar cell. The insulation effect of MLI was verified by environmental test, and its heat transfer model and thermal characteristics were analyzed. The main conclusions are as follows.

(1) The equivalent thermal conductivity coefficients of flexible thin-film solar cell and Nomex honeycomb are calculated as $0.2246 \mathrm{~W} /(\mathrm{m} \cdot \mathrm{k})$ and $0.021 \mathrm{~W} /(\mathrm{m} \cdot \mathrm{k})$, respectively.

(2) MLI has a good heat insulation performance of $36.5^{\circ} \mathrm{C}$. The temperature difference between the layers of flexible thin-film solar cell, PET, and fiberglass mesh is small due to the small thickness and heat resistance, whereas the temperatures of the epoxy resin film and Nomex honeycomb decrease dramatically due to their large thermal resistance caused by the hollow structure.
(3) The heat transfer model established in the paper and simulation results of MLI agree well with the environmental data. It can be concluded that the simulation results are accurate and that the heat transfer model is reliable.

(4) FLUENT is used for modeling and simulation analysis on the flexible thin-film solar cell and MLI, and the results agree well with the environmental test data.

In some way, our study can provide support for further engineering application of flexible thin-film solar cell. Our future research will focus on the effects of MLI on the thermal characteristics and output efficiency of the photovoltaic array, and the effects of MLI on thermal characteristics of the airship.

\section{Conflict of Interests}

The authors declare that they do not have any commercial or associative interest that represents a conflict of interests in connection with the work submitted.

\section{Acknowledgments}

This work was supported by the National Natural Science Foundation of China under Grant no. 51307004 and Shanghai Aerospace Science and Technology Innovation Fund no. SAST201268.

\section{References}

[1] L. Liao and I. Pasternak, "A review of airship structural research and development," Progress in Aerospace Sciences, vol. 45, no. 45, pp. 83-96, 2009.

[2] A. Colozza, "Initial feasibility assessment of a high altitude long endurance airship," Tech. Rep. NASA CR-21272, 2003. 
[3] K. Eguchi, Y. Yokomaku, and M. Mori, "Feasibility study program on stratospheric platform airship technology in Japan," AIAA Paper 99-3912, 1999.

[4] D.-M. Kim, Y.-G. Lee, W.-G. Kang, J.-W. Lee, and C.-H. Yeom, "Korea stratospheric airship program and current results," in Proceedings of the 3rd Annual Aviation Technology, Integration, and Operations (ATIO) Forum (AIAA '03), pp. 2003-6782, November 2003.

[5] K. Harada, K. Eguchi, M. Sano, and S. Sasa, "Experimental study of thermal modeling for stratospheric platform airships," AIAA Paper 2003-6833, 2003.

[6] H. Naito, K. Eguchi, and T. Hoshino, "Design and analysis of solar power system for SPF airship operations," in International Balloon Technology Conference, 1999, AIAA Paper 1999-3351.

[7] J. Shi, X. Zhu, and S. Sui, "Modeling and analysis of solar energy collected by stratosphere airship's surface," Computer Simulation, vol. 24, no. 8, pp. 64-67, 2007 (Chinese).

[8] W. Zheng, Q. Song, Y. Li, Z. H. Wu, and L. Y. Hu, "Computation and analysis of power generated by the solar cell array of a stratospheric airship," Journal of Astronautics, vol. 31, no. 4, pp. 1224-1230, 2010 (Chinese).

[9] X. Li, X. Fang, and Q. Dai, "Research on thermal characteristics of photovoltaic array of stratospheric airship," Journal of Aircraft, vol. 48, no. 4, pp. 1380-1386, 2011.

[10] Eskind, G. Larry, Aanestad et al., "Multilayered flexible fireretardant isolative sheets comprising laminates of insulation layers and fire-retardant glass fiber layers and aluminum foil films," WO Pat, 2001043972, 2001.

[11] C. Yinbing, Y. Lanfang, W. Guangming et al., "Study on $\mathrm{Al} / \mathrm{PI} / \mathrm{SiO}_{2}$ multilayer insulation," Materials Science and Engineering, vol. 21, no. 2, article 221, 2003 (Chinese).

[12] Y. Weidong, Y. Qinhua, H. He, M. Zhiping, C. Nanliang, and Z. Quan, "Preparation and applications of an adiabatic thin soft compound fabric," CN Patent ZL 200410066650.2.2004-09-24, 2004 (Chinese).

[13] Y. Ahluwalia, M. Kiik, and T. Karol, "Composite material," US Patent US20040229053 A1, 2004.

[14] W. Liang, Z. Liu, H. Mai, and J. Yang, "Theoretical calculation for thermal properties of honeycomb structure based on the radiation and conduction coupling model," Structure \& Environment Engineering, vol. 35, no. 4, pp. 31-36, 2008.

[15] R. T. Swarm and C. M. Pittman, "Analysis of effective thermal conductivities of honeycomb-core and corrugated-core sandwich panels," NASA Technical Note D-714, 1961. 

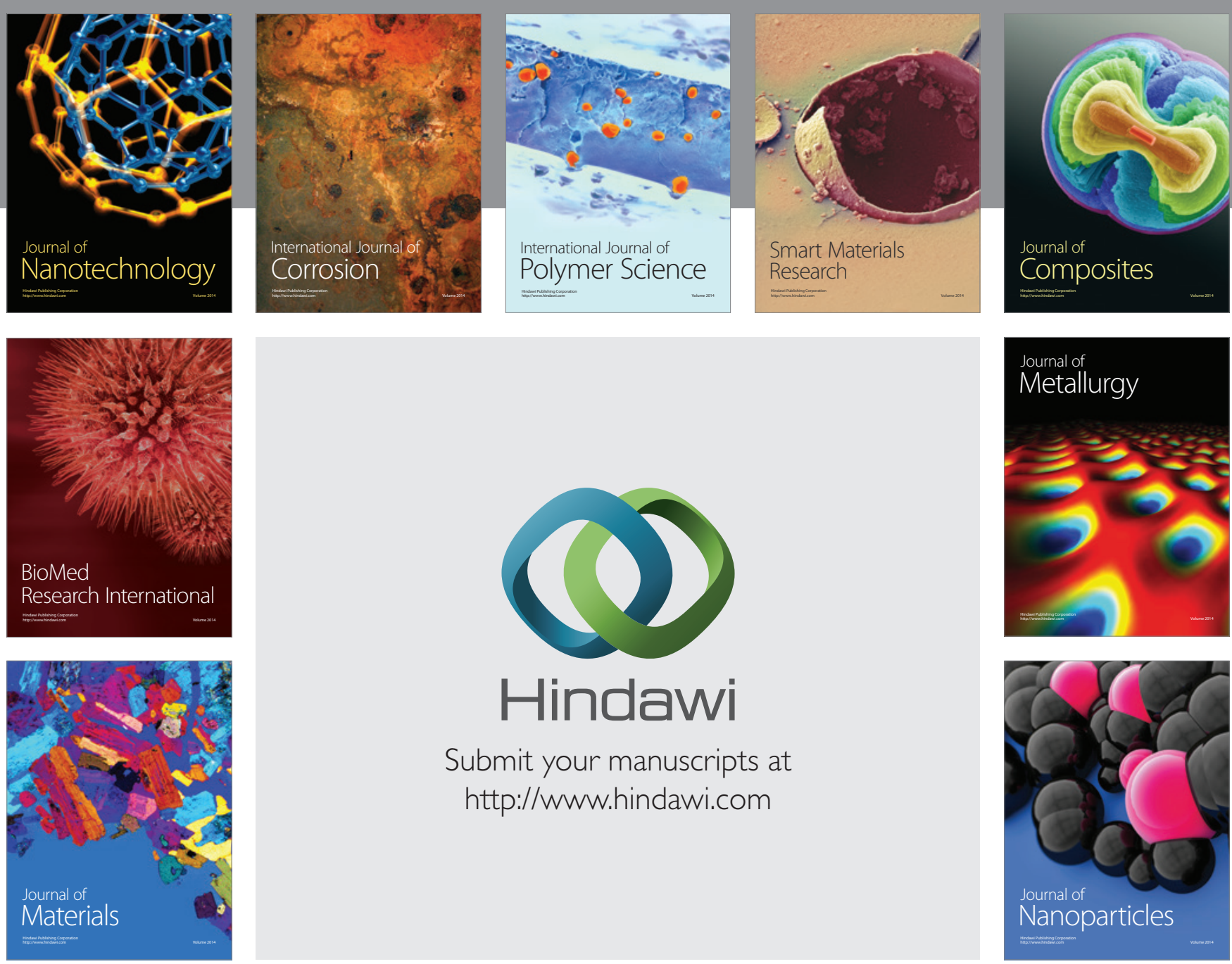

Submit your manuscripts at http://www.hindawi.com
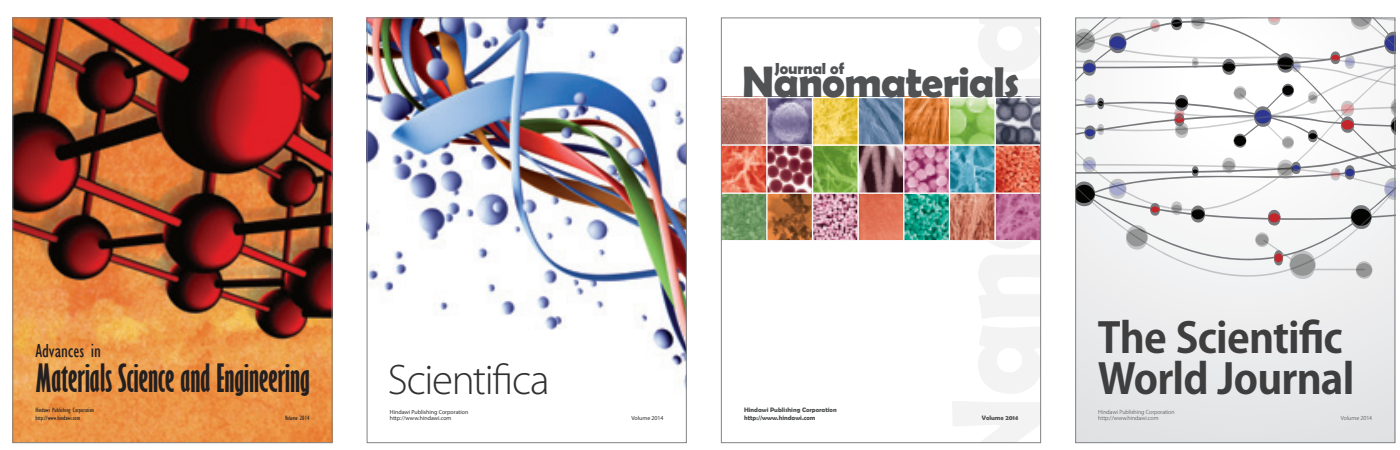

\section{The Scientific World Journal}
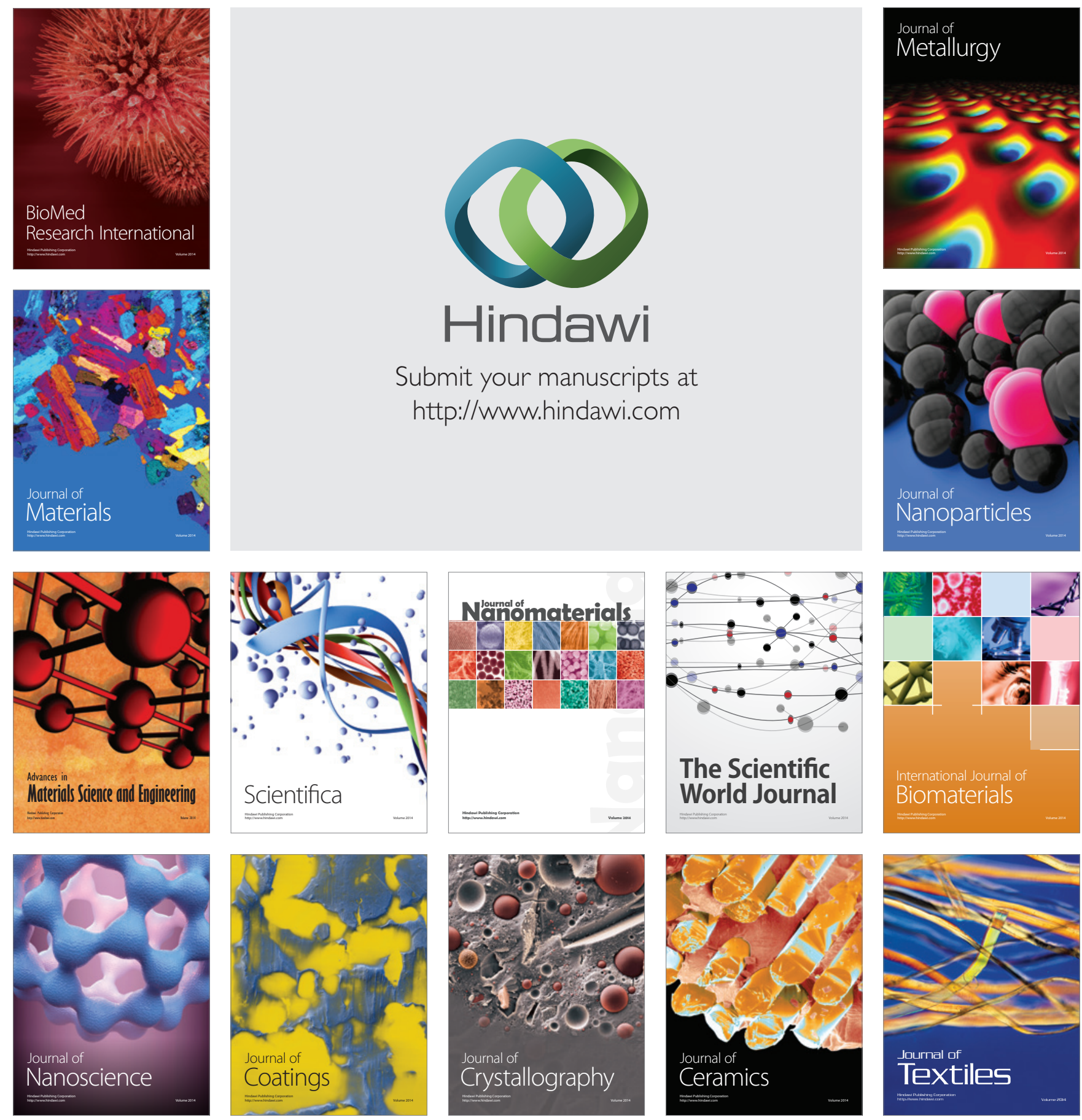